\title{
The experience of intercultural communication between Russian refugees and Filipinos on Tubabao Island, 1948-1951
}

\author{
Charie Ann Cabides-Padullo
}

Leyte Normal University, Tacloban City, Philippines

$\checkmark$ c.padullo@lnu.edu.ph

\begin{abstract}
The article examines the history of Russian immigrants on the Philippine Island of Tubabao, where they fled from China in 1948 to avoid repatriation to the USSR. The refugees lived on the island for four years, a period the local population remembers as "Tiempo Russo." The author's goal was to examine how Filipinos saw the Russians by interviewing older islanders who had had direct contacts with the emigrants. The survey focused on three topics: 1) Fears of the Russians when they arrived on the island; 2) Formal and informal social means of communication between natives and Russians; 3) The level of respondents' trust in Russian refugees. The interviews revealed that the large number of refugees $(6,000)$ who arrived on the island initially aroused apprehension among the local population. However, the Russians' good behavior, friendliness and openness eventually dispelled all fears. The Russians and the islanders developed stable links as they bartered products and carried out leisure activities together, among others. At the same time, the islanders were introduced to Russian everyday culture: playing the piano, watching movies, drinking alcohol (coconut wine). In general, the local population saw their temporary positive effects. They made an impression as open, friendly, hospitable people, who loved to drink and treat others very well.
\end{abstract}

Keywords: Russian emigration, Russian diaspora, adaptation, imagology, resettlement, refugees

For citation: Cabides-Padullo, Charie Ann. "The experience of intercultural communication between Russian refugees and Filipinos on Tubabao Island, 1948-1951." RUDN Journal of Russian History 20, no. 4 (November 2021): 579-587. https://doi.org/10.22363/2312-8674-2021-20-4-579-587

\section{Опыт межкультурной коммуникации русских эмигрантов с филиппинцами на острове Тубабао, 1948-1951 гг.}

\author{
Чари Энн Кабидес-Падулло \\ Педагогический университет Лейте, Таклобан, Филиппины \\ $\checkmark$ c.padullo@lnu.edu.ph
}

\begin{abstract}
Аннотация: Статья посвящена истории русских эмигрантов на филиппинском острове Тубабао, куда они бежали из Китая в 1948 г., когда им угрожала опасность репатриации в СССР. На острове беженцы прожили четыре года, вошедших в историю острова, который получил название «Тьемпо Руссо». Целью исследования является выяснение характера восприятия филиппинцами русских поселенцев через анализ интервью, взятых автором статьи у старшего поколения островитян, имевших непосредственный опыт общения с русскими эмигрантами. Опрос содержал следующие ключевые моменты: 1) чувство опасности, связанное с прибытием русских на остров; 2) формальные и неформальные социальные способы общения между туземцами и русскими; 3) уровень доверия респондентов к русским беженцам. В результате анализа собранного
\end{abstract}


материала удалось установить, что чрезмерное число переселенцев на острове (6 тыс. чел.) первоначально вызывало у местных жителей тревогу за собственную безопасность. Однако характер поведения самих русских, их дружелюбие и открытость в дальнейшем развеяли все страхи. Между русскими и островитянами установились устойчивые связи, в рамках которых были выработаны коммуникативные практики, выражавшиеся в интенсивном продуктообмене, совместном проведении досуга и проч. Одновременно происходило приобщение туземцев к русской повседневной культуре: игре на фортепьяно, просмотру кинофильмов, употреблению алкоголя (кокосового вина). В целом восприятие русских местными жителями носило положительный характер. Они запомнились людьми открытыми, «нестеснительными», дружелюбными, гостеприимными, любившими выпивать и угощать.

Ключевые слова: русская эмиграция, русская диаспора, адаптация, имагология, переселение, беженцы

Для цитирования: Cabides-Padullo Ch.A. The experience of intercultural communication between Russian refugees and Filipinos on Tubabao Island, 1948-1951// Вестник Российского университета дружбы народов. Серия: История России. 2021. Т. 20. № 4. С. 579-587. https://doi.org/10.22363/23128674-2021-20-4-579-587

\title{
Introduction
}

In 1948, fearing repatriation to the Soviet Union, some 6,000 refugees who had fled China were hosted by the Philippine Government on Tubabao Island. They stayed for four years, a time that the locals affectionately remember as "Tiempo Russo."

Ever since the upheavals of revolution and civil war had forced them to flee their homeland to China 25 years earlier, communities of Russians had prospered in such cities as Harbin, Shanghai and Beijing. ${ }^{2}$ As the Chinese communists, backed by the Soviet Union, began defeating the Nationalist government's forces, they began forcibly repatriating Russian émigrés under their control back to the USSR. Thus, some 40,000 Cossacks were sent back north across the border, only to be marched off to GULAG in the Soviet Far East. Fearing a similar fate, a group of 6,000 White Russians still in China sent pleas for sanctuary to several countries through the International Refugee Organization (IRO). ${ }^{3}$ Many replied sympathetically, but only Philippine President Elpidio Quirino provided concrete help, by offering Tubabao Island as a temporary refuge. According to Kinna Kwan, Senior Researcher at the President Elpidio Quirino Foundation, for the locals on the island, "these four years comprise a very fascinating period they fondly refer to as the Tiempo Russo, or the Time of the Russians." She explained:

\begin{abstract}
The camp eventually grew to be a thriving 'little Russian city,' divided into 14 main districts with democratically-elected leaders, and with communal kitchens, power stations, Russian schools, a hospital and a dental clinic, an arbitration court, a police force and a little jail, and several churches for different faiths, including a wooden Russian Orthodox church built from an abandoned church left by the Americans. ${ }^{4}$
\end{abstract}

This article is about the White Russian refugees who were hosted on Tubabao Island from 1949 to 1953. Like their compatriots who had settled abroad elsewhere, they brought along their culture and customs, creating a little Russia. Unfortunately, not much research has been done about how the local population regarded the new arrivals, nor about how they interacted.

${ }^{1}$ Ajay Kamalakaran, "When the Philippines Welcomed Russian Refugees," Russian Beyond the Headlines July 5, 2015, https://www.rbth.com/arts/2015/07/07/when_the_philippines_welcomed_russian_refugees_47513.html

2 Sheng Mao, "Frontier politics and Sino-Soviet relations: a study of Northwestern Xinjiang, 1949-1963." (PhD diss., University of Pennsylvania, 2017).

${ }^{3}$ Now the United National High Commissioner for Refugees - UNHCR.

${ }^{4}$ Kamalakaran, "When the Philippines Welcomed Russian Refugees," 2. 
Located some 15-20 minutes from the mainland, off the southeastern point of Samar Island, Tubabao is part of the municipality of Guiuan Eastern Samar. The island's population largely supports itself by fishing and is divided into five barangays (villages): Camparang, San Antonio, San Juan, San Pedro and Trinidad.

This study asks three questions:

1) What were the experiences of the island's inhabitants who had a firsthand knowledge of the émigrés?

2) To what extent did formal and informal social networks form between the local population and the refugees?

3) What are the perceptions of safety and trust between the locals and the refugees?

Understanding the interconnectedness and relationships formed between the native population and the Russians provides a positive corrective to fears about accepting refugees from other countries today. This paper also hopes to remind the islanders about their own rich history so that they can better appreciate it and tell future generations about the time that White Russians found asylum in their midst.

The definition of the word "refugee" was vague until its implicit adoption by the U.N. High Commission for the Refugees (UNHCR). Formerly known as the International Refugee Organization, the UNHCR is the primary institution for providing support to refugees all over the world. According to one of its reports,

UNHCR has an interest in the protection and welfare of the persons who have been displaced by persecution, situations of general violence, conflict or massive violations of human rights, because of their similarity to refugees in terms of the causes and consequences of their displacement and humanitarian needs. ${ }^{5}$

By the same token, UNHCR also shifted the emphasis on the meaning of protection. Rather than being considered as providing legal asylum, it is now seen as security for refugee operations. ${ }^{6}$ The objective of the White Russian refugees who found a temporary home in Tubabao was mainly to secure legal asylum. The fact that the Philippines welcomed them was hardly unusual, and even today it opens its doors to Afghans seeking a safe harbour. According to Azer Paroccha, President Rodrigo Duterte himself reiterated the Philippines' willingness to accept refugees in his first address to the United Nations General Assembly in September 2020: "The Philippines continues to honor this humanitarian tradition in accordance with our obligations under the 1951 Convention on the Status of Refugees and the 1967 Protocol," the statesman declared. ${ }^{7}$

Because of the influx of North Korean refugees into their country, South Korean academics and government officials have paid particular attention to the question of refugee integration as well as resettlement. In recent years, they have been particularly interested in such aspects as assimilation, social adaptation, public opinion towards North Koreans and South Korea, and other issues concerning the resettlement of North Koreans in South Korea. ${ }^{8}$

Integration with the host country's local population is critical for those seeking asylum there. The former should understand the reasons why refugees seek a different home

\footnotetext{
${ }^{5}$ Internally Displaced Persons: The Role of the United Nations High Commissioner for Refugees (n.p.: UNHCR, 2000), 1-2.

${ }^{6}$ Howard Adelman, "Refugees and Border Security Post-September 11," Refuge: Canada's Journal on Refugees 20, 4 (2002): 5-14. 2002. https://doi.org/10.25071/1920-7336.21268

7 Azer Parrocha, "Afghan Refugees Welcome in Ph:Palace" Philippine News Agency, 17 August 2021, https://www.pna.gov.ph/articles/1150713

${ }^{8}$ Andrei Lankov, "Bitter Taste of Paradise: North Korean Refugees in South Korea," Journal of East Asian Studies 6, 1 (2006): 105-37.
} 
Canada has also had experience accepting refugees. Its first encounter with Asian refugees was in 1970, when the federal government sponsored a group of 228 Tibetans. Because of uncertainty about their religious and cultural requirements, upon arrival the Tibetans faced greater challenges than refugees from other countries. Michael Lampheir noted that Tibetans found it hard to adjust and were therefore more isolated from the Canadian population than both the refugees and their government sponsors would have preferred. ${ }^{9}$

Interaction with the host country's population is a prerequisite for refugees to familiarize themselves with the former. They would find it difficult to blend in with the local inhabitants if they remain aloof. Therefore, it is vital that the host country's officials make them aware of this important duty.

Understanding how refugees and the host country's population interact is an increasingly important task for those working on refugee and migration issues. This includes international and national NGOs, academics and civil society. Although there is evidence that refugees and migrants can contribute significantly to the host country's society if given the opportunity to do so, interaction and agreement between locals and refugees has a significant bearing on their prospects. ${ }^{10}$ Regardless of how much money NGOs and other agencies raise to deal with refugees, what matters most is the public's attitude and the relationship that it will form toward refugees.

The picture is more mixed elsewhere: a 2016 survey in 11 countries found that there was majority support for compassion towards refugees, as well as for accepting them. But connections have recently been made between refugees and security threats, which may be starting to erode refugees' more favored status. ${ }^{11}$ In most societies the impressions of having foreign people in their land can arouse fear and suspicion.

Many studies show clear distinctions in public attitudes based on refugees' and migrants' characteristics. Evidence from the UK, for instance, suggests that people tend to react negatively when asked about "immigration", but are much less prone to do so when asked about specific groups of migrants. ${ }^{12}$ In particular, people tend to be more favourably disposed towards those seen as refugees than they are towards asylum-seekers and other migrants.

This clear distinction needs to be taught to the local population hosting the refugees. Without knowing about the immigrants about to arrive in their communities, they will worry that they might be putting their safety at risk. There is little detail about the perception of the locals in Tubabao when the White Russian refugees arrived. However, it cannot be denied that their first reaction was to think about their safety. ${ }^{13}$

Concerns about security have become another key factor driving attitudes about the relationship between the host population and refugees. A 2016 poll by the Brookings Institution showed that $46 \%$ of Americans who oppose accommodating refugees were concerned about possible links to terrorism. ${ }^{14}$ In another US study, even one-third of those who supported accepting refugees expressed concerns about the safety of doing so. ${ }^{15}$

${ }^{9}$ Michael C. Lanphier, “Canada's Response to Refugees," The International Migration Review 15, 1/2 (1981): 113-30, https://doi:10.2307/2545331

${ }^{10}$ Pantuliano, S., "3 Ways for Countries to Build Resilience to Mass Refugee Flows," Huffington Post, 19 January 2016.

${ }^{11}$ Public Perceptions of the Refugee Crisis (New York: TENT Foundation, 2016).

12 R. Ford, G. Morrell, and A. Heath, "'Fewer but better'? Public views about immigration," in Park, A., Clery, E., Curtice, J., Phillips, M., and Utting, D., eds. British Social Attitudes: The $29^{\text {th }}$ Report (London: Nat Cen Social Research Publ., 2012), 2.

${ }^{13}$ Helen Dempster, and Karen Hargrave, "Understanding Public Attitudes Towards Refugees and Migrants." Icelandic Review of Politics \& Administration 16, 2 (2020): 6.

${ }^{14} \mathrm{~S}$. Telhami, American attitudes on refugees from the Middle East (Washington DC: The Brookings Institution, 2017).

${ }^{15}$ J. Tolay, Refugees: Is There Room for a Middle Ground? (London: The Conversation, 2017). 


\section{Theoretical framework}

This study's theoretical framework is Social Constructivism, which best explains the refugee-host relationship. The author mostly relied on Social Constructivism to analyse interaction among the locals and the White Russian refugees.

Immanuel Kant was a forerunner of Social Constructivism. He argued that our knowledge about the world is subjective rather than objective because it is formed through human consciousness. ${ }^{16}$ Refugees can be seen as a social construct because they result from human conflicts. Therefore, the relationship between refugees and the host's population, whether it be negative or positive, is a social construct that ultimately affects how integration occurs at the local level.

Integration is not a one-way street. The local population can also learn from the behavior of the refugees. This can create new social constructs as they observe the different practices of the refugees. When the White Russians arrived in Tubabao, the islanders did not know their habits and culture. Through observation and interaction, the locals began to understand some of their practices. For example, the Russians were fond of bathing on the beach. As they did so, the ladies would wear almost nothing. But the islanders noticed that they valued the upper part of their bodies rather than the lower, since the women believed that, since they did not have the former when they were very young, it was more valuable.

At the same time, whenever the refugees took something from the islanders, they gave something in return or even paid for it. In general, the locals learned more from the Russians than the other way around. People who write about Social Constructivism tend to look at what newcomers acquire from the people and the place where they settle, but in this case it was the islanders who gained something from the refugees.

\section{Methodology}

The study employed qualitative hermeneutics phenomenological design to examine the interaction between the local population and the refugees. Qualitative design is probably the most flexible of the acceptable techniques for such an analysis. ${ }^{17}$

The main respondents of the study were members of the Tubabao's population aged over 75 years and had lived with the White Russian refugees. They were recommended by the locals and the barangay captain to the researcher, who conducted interviews and focused group discussions that were recorded.

Table

Oldest locals in Tubabao Island

\begin{tabular}{lcc}
\hline & Age at present (2019) & Age during 1949 (Tiempo Russo) \\
\hline Participant 1 & $99 \mathrm{y} / \mathrm{o}$ & $29 \mathrm{y} / \mathrm{o}$ \\
Participant 2 & $79 \mathrm{y} / \mathrm{o}$ & $9 \mathrm{y} / \mathrm{o}$ \\
Participant 3 & $88 \mathrm{y} / \mathrm{o}$ & $18 \mathrm{y} / \mathrm{o}$ \\
\hline
\end{tabular}

Informed consent was provided to all participants before the interviews. Some participants needed assistance, often from a close relative. Fortunately, only one participant required some help due to poor hearing. All interviews lasted between 30 to 45 minutes, which provided enough time to obtain a detailed response. To establish rapport, the re-

16 Adina Davidovich, "Kant's Theological Constructivism," The Harvard Theological Review 86, 3 (1993): 323-51.

${ }^{17}$ M. Shuttleworth, and L. Wilson, "Qualitative Research Design,” Explorable, accessed 29 August 2021, https://explorable.com/qualitative-research-design 
searcher began with a probing question, such as "Would you mind describing your first encounter with the Russians?", "Could you share to us the interaction that took place between the locals and the refugees?", "How would you describe their stay in your island?" and "What else did you experience when they were in your community?"

To encourage the participants to elaborate, they were also asked descriptive questions, including, "Why did that happen?" and "How do you think does that relate to the previous responses?" And there were also judgmental questions to assess whether respondents had positive or negative memories of their encounters with the White Russians. All interviews were recorded and transcribed to provide the data for the study.

\section{Data analysis}

The study was based on M. Firouzkouhi and Ali Zargham-Boroujeni's method for studying oral history. Their approach is thoroughly to analyse the data gathered through interviews and group discussions. Identifying common responses should identify clear connections among varied categories and shape a collective narrative.

The data analysis was based on the four-stage method of oral history. In the first step the initial codes were extracted from each interview separately. The recordings of interviews were transcribed and substantial words, phrases, sentences, or paragraphs were highlighted as initial codes. Subcategories were then established from the initial codes, and ultimately these categories were used to identify narrative themes. Extensive data were collected through probing questions and the in-depth discussion. ${ }^{18}$

The study's respondents were interviewed in their homes with the consent of the barangay captain as well as of the participants themselves. Given their advanced age, consent was also obtained from their children or other relatives in their households. Should there be any objections, the interview could be stopped at any time. The participant's names were assigned to numbers to guarantee anonymity.

The interactions with the White Russian refugees were an important chapter in islanders' local history, which suggests that ties between them were strong.

\section{Formation of social networks}

As the White Russians arrived on Tubabao Island they formed social networks among themselves as well as with the local population. The interviews revealed not only that the islanders did not object to the presence of the refugees, but they were also socialized with them.

Participant 1 stated:

They were very friendly, they are not shy people. They would really interact with us. I even had friends, Bienbi, Nina and Gabby, they were close to me. We were mostly spending time together because they were so fond of me.

\section{He added:}

Yes, all the time they would give me a huge loaf of bread, then we would drink coconut wine. They liked the wine and they drank a lot.

The interviewee kept on repeating these three names during the interview and his daughter even mentioned that this was just one of the many stories that her father used to tell them when she was young.

${ }^{18}$ Mohammadreza Firouzkouhi and Ali Zargham-Boroujeni, "Data analysis in oral history: A new approach in historical research.” Iranian Journal of Nursing and Midwifery Research 20, 2 (2015): 161-4. 
1. Russian Bread Connections. Bread seemed to be a tool for interaction between the two groups. It is also a commodity that can be traded.

Participant 1 said:

Their bread was so delicious! I would ask for some bread, apples and oranges from them and use them as gifts to the woman I was courting.

He added that the refugees were given food, which they shared with the islanders. The local population likewise shared what they had.

Participant 2:

At daybreak I would run to their camp together with my other friends and we would ask for their bread. They gave it to us for free. Sometimes, when they gave me bread I would give them young coconuts or even flowers, which pleased them. This is what I usually did, to get bread from them. This became my routine.

\section{Participant 3:}

I have a friend named George. When I arrived home from school in the mainland, in Guiuan, my parents would tell me "Juanito you have a visitor". George would always bring bread to the house and we would eat it as a snack. After that we would go out together with my other friends. They called me "shorty" back then, maybe because I was too short at the time.

2. Challenges to Trust and Safety. Since the refugees arrived in large numbers the first concern of the local population was about its safety. However, over time the islanders clearly understood that their stay would be temporary. The locals added that the Russians were well behaved and did not harm them.

\section{Participant 2:}

There were no evident conflicts between the locals and the refugees, because the locals were very welcoming and helpful, and the Russians were also very good people, I cannot say anything. They should be good because if they harm us we will also do that to them.

\section{Participant 3:}

It was easy to go to their camp. I just showed my ID, then they would know that I am a student, which made it easy to enter. There was a soldier guarding them when they were staying on the island.

They were very kind people; I cannot say anything bad about their presence. They were treated very well, and there really were no differences among us.

Based on their responses, the islanders were not worried about their safety. The refugees stayed in their own little city, or what could better be called the Russian City on an island of the Philippines. The locals maintained a good relationship with the White Russians, and they said that they treated them well. They added that refugees should act politely, especially since they were foreign to the island.

3. Association through Recreation. The islanders are fond of various recreational activities. They seem to have influenced the refugees how to drink and bathe at the beach, among others. But when it came to music, the White Russians made their own. Some of them were piano teachers and they also played other musical instruments. These were the basic ways that the locals and the refugees engaged in recreational activity together.

Participant 1:

Yes, they would always give me a large loaf of bread, then we would drink coconut wine. They liked the wine and they drank a lot.

They didn't really dance, and prefered to converse and drink. 


\section{Participant 2:}

There is a very nice cinema by the beach in Camparang, where we would watch movies every night.

The White Russians also set up a mini theatre on Camparang's shore, where everybody was allowed to watch the movies, they showed. The cinema encouraged the locals to interact with them. These were just some of the responses. At the same time, drinking "tuba" (coconut wine) was also a popular form of recreation, and it is still practiced in the island.

\section{Conclusion}

This study highlights the desire of the islanders to understand the complexities of their interaction with the refugees. But it focused more on how they experienced the presence of the Russians as well as on how they integrated with the refugees. ${ }^{19}$ In recent years, Russian ambassadors have occasionally visited the Philippines and organised commemorations in Guiuan and on Tubabao to mark the four-year asylum they have spent in our country. ${ }^{20}$

The first encounters of the locals and the refugees seem to have left a positive impression. The islanders were aware that the government had allowed the White Russians to stay on their island temporarily, and therefore did not worry about their safety. Furthermore, the refugees did not threaten them. The locals saw no reason to worry because they liked how the Russians treated them, and they did not cause any conflicts.

The history of the Russians on the Tubabao is a positive example of social integration. It is important that subsequent generations of islanders know about Tiempo Russo and, more generally, how ties with other nations can be good. The study recommends that the story of the refugees be integrated in the island's local history and be taught to its schoolchildren, all the more so since Russians visit it almost every year to commemorate the refuge its people offered to their compatriots. At the same time, this happy episode should encourage others to welcome refugees in our own time.

Поступила в редакцию / Submitted: 09.03.2021

Одобрена после рецензирования / Approved after reviewing: 30.09.2021

Принята к публикации / Accepted for publication: 04.10.2021

\section{References}

Adelman, Howard. "Refugees and Border Security Post-September 11." Refuge: Canada's Journal on Refugees 20, 4 (2002): 5-14. 2002. https://doi.org/10.25071/1920-7336.21268

Dempster, Helen, and Karen Hargrave, "Understanding Public Attitudes Towards Refugees and Migrants." Icelandic Review of Politics \& Administration 16, 2 (2020): 217-42.

Ford, R., G. Morrell, and A. Heath, “'Fewer but better?' Public views about immigration”. In Park, A., E. Clery, J. Curtice, M. Phillips and D. Utting. British Social Attitudes: The $29^{\text {th }}$ Report. London: NatCen Social Research Publ., 2012.

Kamalakaran, Ajay. "When the Philippines Welcomed Russian Refugees." Russia Beyond the Headlines, 5 July 2015, https://www.rbth.com/arts/2015/07/07/when_the_philippines_welcomed_russian_refugees_47513.html

Lankov, Andrei. "Bitter Taste of Paradise: North Korean Refugees in South Korea." Journal of East Asian Studies 6, 1 (2006): 105-37. Accessed August 29, 2021. http://www.jstor.org/stable/23418172

${ }^{19}$ C. Richoufftz, "From Research to Outreach to Action: Community-based approaches to the integration of refugees and asylum seekers in Montreal." Samuel Centre for Social Connectedness, August 6, 2018, https://www.socialconnectedness.org/wp-content/uploads/2019/10/Community-based-approaches-to-theintegration-of-refugees-and-asylum-seekers-in-Montreal-1.pdf

20 R. Amazona, "Samar's contribution to Russian history to be promoted," Philippine News Agency, November 30, 2018, https://www.pna.gov.ph/articles/1055397 
Lanphier, Michael C. "Canada's Response to Refugees." The International Migration Review 15, no. 1/2 (1981): 113-30, https://doi:10.2307/2545331

Mao, Sheng, "Frontier politics and Sino-Soviet relations: A study of Northwestern Xinjiang, 1949-1963." $\mathrm{PhD}$ diss., University of Pennsylvania, 2017.

Pantuliano, S., "3 Ways for Countries to Build Resilience to Mass Refugee Flows," Huffington Post, 19 January 2016.

Parrocha, Azer. “Afghan Refugees Welcome in PH:Palace.” Philippine News Agency, 17 August 2021, https://www.pna.gov.ph/articles/1150713

Telhami, S. American attitudes on refugees from the Middle East. Washington DC: The Brookings Institution, 2017.

Tolay, J. "Refugees: Is there Room for a Middle Ground?" The Conversation, 13 February 2017, https://theconversation.com/refugees-is-there-room-for-a-middle-ground-72634

\section{Информация об авторе / Information about the author}

Ч.Э. Кабидес-Падулло, магистр социальных наук, профессор отделения социальных наук, координатор отдела исследований, 6500, Филиппины, Таклобан, ул. Патерно, 35, c.padullo@lnu.edu.ph
C.A. Cabides-Padullo, Licensed Professional Teacher, Master of Arts in Teaching Social Science, Professor in the Social Science Unit, Unit Research Coordinator, 35, Paterno St., Tacloban City, 6500, Philippines, c.padullo@lnu.edu.ph 